オゾンを用いた表面処理方法

黒 河明*1

\title{
Surface-Treatment Methods Using Ozone
}

Akira KUROKAWA*1

${ }^{* 1}$ National Institute of Advanced Industrial Science and Technology (AIST), 1-1-1 Higashi, Tsukuba-shi, Ibaraki 305-8565, Japan

(Received February 18, 2013, Accepted June 17, 2013)

\begin{abstract}
Surface-treatment methods using ozone, such ozone gas treatment with UV light irradiation, immersion in ozone diluted water, and exposure to ozone gas are discussed herein. The objectives of performing ozone surface treatments are to reduce carbon-related contamination on the surface, prepare a clean substrate surface to fabricate a thin-film stacking with sharp interfaces, oxidize a surface to form high-quality oxide thin films, and passivate a metal surface to increase its corrosion resistance. These objectives are achieved because of the high oxidation ability of the ozone molecules and the oxygen radicals resulting from the ozone dissociation. Various applications of ozone surface treatment are also exemplified in this report to reveal their significant potential as surface-treatment tools.
\end{abstract}

\section{1. はじめに}

オゾンは強力な酸化作用を持ち，ほとんどの金属を容易に 酸化し，また多数の有機物や無機物と反応してその分解を行 う.この酸化作用に起因して殺菌（滅菌・防力ビ）・脱色 · 脱臭の作用を持つことが知られ, 上下水処理 - 工業排水処理 等の水処理への応用が実用化されて久しく, 医療現場・食品 加工現場などへの適用も図られている. 工業分野でも半導体 素子製造用の精密洗浄やパルプの漂白などをはじめオゾンの 用途は広がっている. 材料表面の清浄化処理では, オゾン処 理に適した用途が多数あり，新機能素子を作製するための基 板表面の精密洗浄処理や, 極端紫外光用光学部品の表面污染 除去などへの利用が検討されている.

オゾンの作用は最終的に $2 \mathrm{O}_{3} \rightarrow 3 \mathrm{O}_{2}$ で表される分解反応に 伴うものである. しかしながら, 反応対象の化学構造や水中 または紫外線照射下等の反応環境により，オゾンと対象物質 との反応が複雑な反応経路や多種のラジカル生成を伴う場合 がある、そのためオゾンによる反応では，11オゾンと対象と の直接反応によるものの他に，(2)原子状酸素との反応による ものや(3)ヒドロキシルラジカル $(\bullet \mathrm{OH})$ との反応によるも のなど活性種を伴う反応も存在する. とくに水にオゾンを溶 解させたオゾン水は, オゾン分解反応により生成された・ $\mathrm{OH}$ を含有し ${ }^{1,2)}$, その反応速度定数はオゾンよりも数桁大 きい，そのため污染物の分解と水での除去とによる洗浄作用 を主な目的としたウエット処理法として広く利用されている.

本報告では，オゾンによる表面処理への利用形態として, オゾン水, $\mathrm{UV} / \mathrm{O}_{3}$ 法, オゾン酸化処理法を中心に, 各種材 料のオゾン処理例やオゾン処理状況の観測方法について紹介 する．また表面処理した薄膜の厚さや密度を精密に解析する 方法として X 線反射率法を紹介する.

\section{2. ウエット処理方法としてのオゾン水}

オゾンを水に溶解させると, オゾンよりも反応性の高いヒ

*1 独立行政法人産業技術総合研究所（干305-8565 茨城県つくば 市東 1-1-1)
ドロキシルラジカル $(\bullet \mathrm{OH})$ が生成される.このラジカル は有機物と反応（酸化）して低分子化し, 水により除去可能 な物質に変える.オゾンで酸化されやすい有機物として, 炭 素二重結合を持つ化合物をはじめ, アルコール類, 不飽和結 合を持つオレフィン系やアセチレン系化合物などが知られて いる.オゾンの水溶液中での分解反応とラジカルの生成は下 記で表される3,4).

$$
\begin{array}{lll}
\mathrm{O}_{3}+\mathrm{OH}^{-} \rightarrow \mathrm{HO}_{2}+\mathrm{O}_{2}^{-} & \mathrm{k}=7.0 \times 10 & \mathrm{M}^{-1} \mathrm{~S}^{-1} \\
\mathrm{O}_{3}+\mathrm{O}_{2}^{--} \rightarrow \mathrm{O}_{3}^{-}+\mathrm{O}_{2} & \mathrm{k}=1.6 \times 10^{9} & \mathrm{M}^{-1} \mathrm{~S}^{-1} \\
\mathrm{O}_{3}^{-}+\mathrm{H}^{+} \rightarrow \mathrm{HO}_{3} & \mathrm{k}=5.2 \times 10^{10} \mathrm{M}^{-1} \mathrm{~S}^{-1} \\
\mathrm{HO}_{3} \rightarrow \bullet \cdot \mathrm{OH}+\mathrm{O}_{2} & \mathrm{k}=1.1 \times 10^{5} \mathrm{M}^{-1} \mathrm{~S}^{-1}
\end{array}
$$

このように水中ではオゾンは水酸イオンと反応しオキサイド ラジカル $\left(\mathrm{O}_{2}^{-}\right)$やヒドロペルオキシラジカル $\left(\mathrm{HO}_{2}^{\dot{*}}\right)$ を生 成し，それらはオゾンや $\mathrm{O}_{2}^{-}$との反応により $\mathrm{O}_{3}^{-}$や $\mathrm{HO}_{3}^{+}$と なる過程を経て，オゾン自身よりも酸化力の高い・OH が生 成される. な扮余剒の・OH はオゾンと反応して $\mathrm{HO}_{2}$ に戻る.

オゾン水の反応効果を高めるためには, 水へのオゾン溶解 量を増やしたり, 水中でのオゾン分解速度を高めて・OH 生 成を促進させたりする方法がある。

オゾン溶解量を増やすには, バブリング法, 膜透過法（中 空糸法), 充填塔法などがある. バブリング法の例5)では, オゾンガスを水中に吹き込んだときの泡のサイズをマイクロ バブル（直径～ $50 \mu \mathrm{m} ）$ 化することにより $2.5 \%$ の低濃度才 ゾンガスから $25 \mathrm{ppm}$ 濃度のオゾン水が得られる5).このオ ゾン濃度は通常泡サイズのときに比べて 2.5 倍である.なお 高濃度のオゾンガスを利用すればさらに高濃度のオゾン水を 発生できる. 中空糸法は, 中空糸の壁の内外をそれぞれ純水 とオゾンガスとで満たし, 中空糸壁を透過するオゾンガスが 純水に溶解するしくみで, $100 \mathrm{ppm}$ 濃度のオゾン水を製造 する装置が実用化されている.

溶存オゾンの分解速度を高めるには, オゾン水の $\mathrm{pH}$ 制御 法がある. 式(1)での $\mathrm{O}_{2}^{-}$と $\mathrm{HO}_{2}$ は平衡関係（ $\mathrm{pKa}=4.8 ）$ にあり $\mathrm{pH}$ により存在比を制御できる. pH が高い場合オゾ ンの分解速度が大きくなり・OH生成が促進される. 逆に 
$\mathrm{pH}$ を小さくするとオゾン分解速度は抑制され, 例えば $\mathrm{pH}$ を 7 から 4 に下げると分解速度が $1 / 8$ になる（オゾン濃度 $20 \mathrm{mg} / \mathrm{L}$ で水温 $25^{\circ} \mathrm{C}$ の場合 $)^{6)}$. 高 $\mathrm{pH}$ オゾン水の利用例で

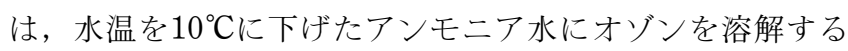
ことでオゾン溶解量とオゾン分解速度を共に増加させ, ラジ カルによる酸化力の向上とシリコン基板洗浄での微粒子除去 効果が検討されている7).

オゾン水を半導体基板の洗浄薬液として利用する利点は環 境負荷の低減である. 薬液を用いるシリコン基板のウエット 洗浄では, 従来過酸化水素々水酸化アンモニウムのアルカリ 性混合液（SC1）に浸漬する洗浄方法と塩酸と過酸化水素の 酸性混合液（SC2）に浸漬する洗浄方法とを組みあわせた洗 浄が行われている．この方法のデメリットは，大量の薬液使 用による高環境負荷の点以外にも, 表面あれの増加, 除去し た粒子の洗浄液からの再付着等である. そこで SC1 や SC2 に替わり，オゾン水とフッ化水素酸を用いる方法が利用され ている. まずオゾン水で基板や金属粒子の酸化を行い，次に フッ化水素酸で污染物ともに酸化膜を除去する方法 $\left(\mathrm{O}_{3}\right.$ 水 $/$ $\mathrm{HF}$ 清浄化）である. $\mathrm{O}_{3}$ 水 $/ \mathrm{HF}$ 清浄化はシリコン基板洗浄 への適用例が多いが $\mathrm{SiGe}$ 基板 ${ }^{8)}$ のような他の材料の表面洗 浄への適用が図られている. $\mathrm{Si}_{1-\mathrm{x}} \mathrm{Ge}_{\mathrm{x}}(\mathrm{x}=0.2-0.5)$ 基板を $\mathrm{O}_{3}$ 水 $/ \mathrm{HF}$ で処理すると $\mathrm{SC} 1$ 洗浄よりも平滑な表面が得ら れ, 表面の酸化膜はほぼ $\mathrm{SiO}_{2}$ である. その厚さは約 $0.9 \mathrm{~nm}$ から約 $2 \mathrm{~nm}$ であり $\mathrm{Ge}$ の成分量に依存する ${ }^{8)}$.

オゾン水は, 半導体基板上の露光レジスト膜の除去処理に も適用が図られている. その目的はレジスト膜除去に使用さ れている硫酸・過酸化水素水などの薬液の代替を図るためで ある ${ }^{4,9)}$. レジスト除去作用はオゾン水中のオゾンやラジカ ルがレジストの化学結合に作用することによるが，レジスト 除去力をさらに増加させる添加剤の探索が行われている.酢 酸を添加するとオゾン溶解量を増やす効果があり，また

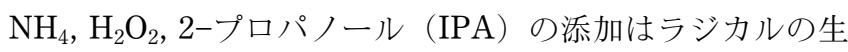
成速度を増やす効果がある。䣷酸添加の例4,9)では, $8.7 \mathrm{M}$ の濃度で添加すると ArF 光用レジスト除去速度が無添加才 ゾン水に比べて 6.8 倍になる。 これは添加により水中での才 ゾン寿命とオゾン溶解量がともに増加するためである。 また IPA $6.5 \mathrm{M}$ の濃度で添加するとレジスト除去速度は 12 倍 になる。これはIPAが・OH と反応して $\mathrm{O}_{2}^{-}$を生じこれが オゾン分解を促進し，その結果・OH 生成速度が加速された ためである ${ }^{4)}$ 。この作用は IPA が低濃度（0.01 M 以下）の 場合に支配的である. IPA 濃度が高い場合は・OH は IPA に より消費されて減少するためIPA そのものによるレジスト 除去作用が支配的になる4 ${ }^{4}$.

オゾン水に添加物を利用する際にはレジスト以外の材料へ の影響も考慮する必要がある．例えば基板表面にタングステ ン配線（W 線）が露出している状態でIPAを添加したオゾ ン水洗浄を行うと, W 線の溶解速度が $1.54 \times 10^{-5} \mathrm{~g} / \mathrm{min}$ に 加速され，W 線が著しく消耗してしまう10)。この原因は IPA 添加で増加したラジカルにより, 水溶性の $\mathrm{WO}_{2}$ が W 線表面に形成される速度が増加したためである. その他, 添 加物の効果にはオゾン濃度も関係している. オゾン水が高濃 度 $(100 \mathrm{mg} / 1)$ の場合は $\mathrm{H}_{2} \mathrm{O}_{2}$ を添加しても増速効果はな
い11)ので, 添加物の効果はオゾン濃度の影響も含めて検討 する必要がある.

オゾン水処理で真空容器の壁面改質を行ってアウトガス特 性が改善された例 ${ }^{12)}$ がある.A6063アルミ合金の試料を6.7 $\mathrm{ppm}$ 濃度オゾン水に 30 分浸漬しベーキングを $120^{\circ} \mathrm{C} て ゙ 24$ 時間 行うと, アウトガス速度は $6.4 \times 10^{-12} \mathrm{~Pa} \cdot \mathrm{m} / \mathrm{s}$ となり，オゾ ン水処理なしの場合に比べてアウトガス速度が $1 / 3$ に改善 される．同様に $2 \mathrm{~m}$ 長のアルミ合金製容器を $2 \mathrm{ppm}$ 濃度才 ゾン水で処理するとアウトガス速度が $4 \times 10^{-11} \mathrm{~Pa} \cdot \mathrm{m} / \mathrm{s}$ と なり, 台湾放射光施設の加速器部品の表面処理法として適用 が図られている。

\section{3. オゾンガスによる金属の表面処理}

\section{1 オゾンガスによるステンレス鋼の表面処理}

配管・バルブ等では接ガス内壁面の表面処理が重要であ る. 表面組成は内部を流れるガスや流体に対する耐腐蝕性を 左右し, 表面の清浄度は流下物の純度維持性能に影響を与え る. 金属の配管材料のうちステンレス鋼やアルミ合金は，そ の表面が自然酸化膜に覆われており，化学的に安定な表面を 与える.ステンレス鋼は, 各種ガスの接ガス基材として, 配 管，バルブ，継ぎ手，ガスケット，フィルター，製造機器な ぞに広く用いられている．ステンレス鋼の表面処理方法では 光輝熱処理 $(\mathrm{BA})$, 電解研磨, 電解複合研磨, 化学研磨など が知られている.

電解研磨処理を施したステンレス鋼管の内壁表面は酸素ガ スとの反応で形成された酸化膜で覆われているが，オゾンを 用いてさらに追酸化を行って酸化膜を改質することができ る. 例えば純水へのステンレス鋼管からの金属溶出量はオゾ ン処理により減少する. ステンレス鋼 (SUS316L) を $80^{\circ} \mathrm{C}$ の超純水中に 10 日間浸漬し $\mathrm{Fe}, \mathrm{Cr}, \mathrm{Ni}, \mathrm{Mn}, \mathrm{Mo}$ の金属溶出量 を誘導結合プラズマ (ICP) 発光分析で定量分析すると ${ }^{13)}$, 金属溶出量は, オゾン処理前は $1445 \mathrm{ng} / \mathrm{cm}^{2}$ であったが, 70 vol\%濃度のオゾンガスに暴露する処理によって464 ng/ $\mathrm{cm}^{2}$ に低減した。 な搈出金属の 8 割は $\mathrm{Fe}$ であった，金属 溶出量の低減は, オゾンの追酸化処理によってステンレス鋼 表面の酸化膜がより緻密となり $\mathrm{Fe}$ 溶出の少ない安定な不動 態被膜が形成されたためと思われる13). ちなみにオゾンの 酸化力は, $70 \mathrm{vol} \%$ のオゾン濃度のガスを用いると, 室温で の処理でも約 $10 \mathrm{~nm}$ の酸化皮膜を形成する能力がある14). ス テンレス鋼繊維を用いた不織布もオゾン処理で同様の効果が 得られている15). $15 \mathrm{vol} \%$ 濃度のオゾンで処理した後に $80^{\circ} \mathrm{C}$ の超純水中に 3 日間浸漬したときの $\mathrm{Fe}$ と $\mathrm{Ni}$ の金属溶出量 はオゾン処理前に比べて $70 \%$ 減少した.

ステンレス鋼の耐蝕性は表面の $\mathrm{Cr}_{2} \mathrm{O}_{3}$ 層に由来する. 緻 密な $\mathrm{Cr}_{2} \mathrm{O}_{3}$ 層を酸素雾囲気下で形成するためには基材の高 温加熱が必要である. 例えば 5 日間 5 気圧 $100^{\circ} \mathrm{C}$ のCl の腐 蝕環境に耐える $\mathrm{Cr}_{2} \mathrm{O}_{3}$ 層を SUS316L 表面に形成するために 温度 $500^{\circ} \mathrm{C}$ 基材を加熱する ${ }^{16)}$. 一方オゾンは, 基材が室温 でも $\mathrm{Cr}_{2} \mathrm{O}_{3}$ 酸化層を形成でき, より高価数の酸化膜も形成 することができる17). Fig. 1 に，室温でオゾン流下処理を 行ったステンレス鋼表面を $\mathrm{X}$ 線光電子分光分析装置 (XPS) で分析した結果を示す。未処理の場合は, $\mathrm{Cr}^{3+}\left(\mathrm{Cr}_{2} \mathrm{O}_{3}\right)$ が 


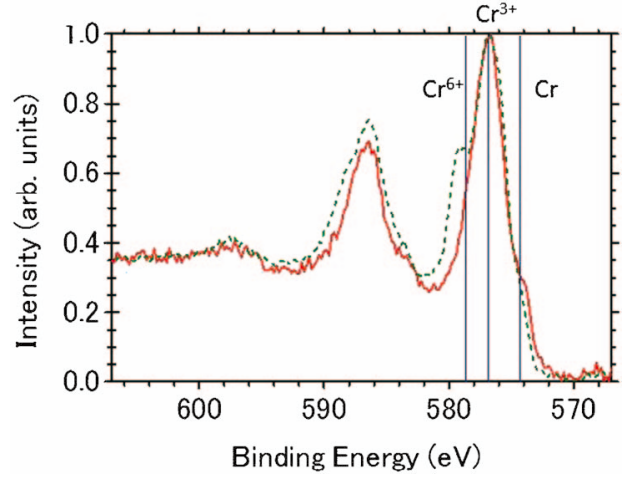

Fig. 1 XPS spectra of the as received SUS304EP surface (solid red) and of that treated with the $126 \mathrm{~L}$ of ozone (27 vol \%) -oxygen gas mixture (dashed green).

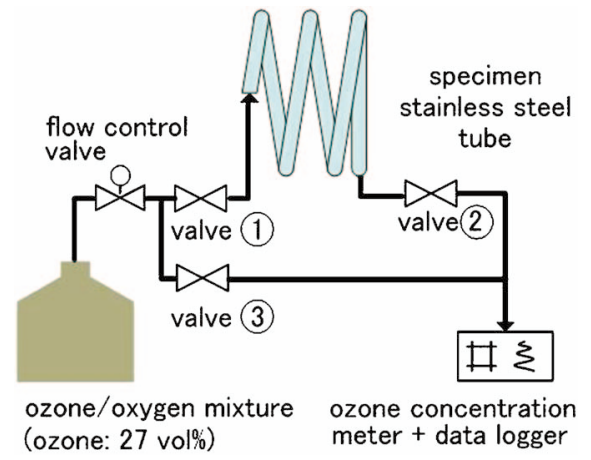

Fig. 2 Experimental setup for the passivation of a stainless steel tube by flowing a mixture of ozone ( $27 \mathrm{vol} \%)$ and oxygen. The passivation was carried out by the ozone gas flowing through valves 1 and 2 . The ozone concentration of the inlet gas was evaluated at the opening of the valve 3 .

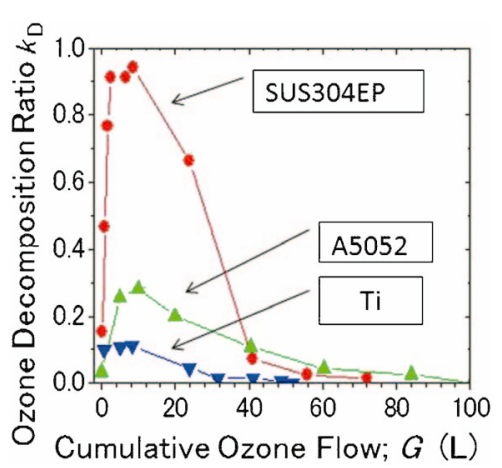

Fig. 3 Changes in the ozone decomposition rate of ozone (27 vol\%) - oxygen gas mixture flown through a SUS304EP tube $(\boldsymbol{O})$, an aluminum alloy tube $(\boldsymbol{\Lambda})$, and a Ti tube $(\boldsymbol{\nabla})$, the diameter of which were $12.7 \mathrm{~mm}$ each.

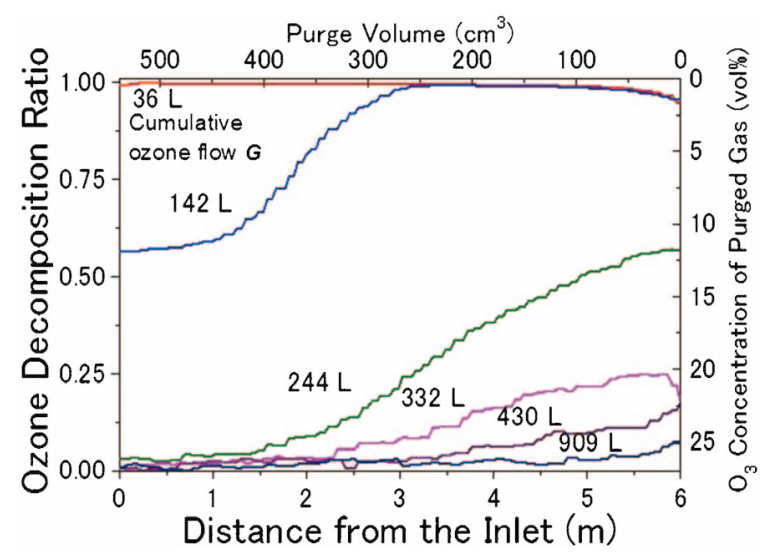

Fig. 4 Spatial distributions of the ozone decomposition rate, derived after a shut-up time of 110 min, over the SUS304EP tube. The cumulative volume of ozone (27 vol\%) - oxygen gas mixture from the top to the bottom for the passivation were $36,142,244,332,430$, and $909 \mathrm{~L}$.

に短時間でオゾン安定化が終了する.

オゾン処理中のステンレス鋼管について入口からの各点で の処理状況を把握することもできる. Fig. 4は長さ $6 \mathrm{~m} の$ ステンレス鋼管の各点でのオゾン処理進行度を示したもので ある21).これは, 所定のオゾン流下処理後, 管内にオゾン 
を110分の間封入し, 次に一定流速でパージしながら押し出 されるガスのオゾン濃度を順次測定したものである．これに よりあらましではあるが管内各点でのオゾン処理進行状況が 得られる.オゾン流下処理の初期 $(G=36 \mathrm{~L})$ にはオゾン分 解率は管全域でほぼ 1 であり, $\mathrm{G}=244 \mathrm{~L}$ 流下処理後では入 口から半分の距離まで分解率 0.2 以下となる処理が進行した ことがわかる.な抢この流下処理では濃度 $27 \mathrm{vol} \%$ の高濃度 オゾンガスを用いた. オゾン処理はオゾン濃度が高い方が効 率的であるが，ステンレス鋼の表面清浄化のみが目的である ならば250 ppmの低いオゾン濃度でも有効である22.

\section{4. $\mathrm{UV} / \mathbf{O}_{3}$ 法による表面洗浄}

オゾンは, 単独でも表面処理法として使用されるが, さら に効果を上げる方法として紫外線（UV 光）を併用する処理 法 $\left(\mathrm{UV} / \mathrm{O}_{3}\right.$ 法) が知られている. 酸素ガスに波長 $185 \mathrm{~nm}$ や $254 \mathrm{~nm}$ を含む UV 光を照射すると, オゾン分子の生成やオ ゾン解離による原子状酸素の生成が生じる. UV 光が試料に 照射されると付着有機物の一部は分解されイオンやラジカル や励起分子となり, これらはオゾンや原子状酸素と反応しや すく，その結果有機物は $\mathrm{CO}_{2}, \mathrm{H}_{2} \mathrm{O}, \mathrm{N}_{2}$ といった除去容易な 分子になる.これが $\mathrm{UV} / \mathrm{O}_{3}$ 法による有機沫染物の除去機構 である23).

$\mathrm{UV} / \mathrm{O}_{3}$ 法は清浄化処理する場合対象物には酸化が伴う. これはオゾンやラジカルといった酸化活性種に処理材料が曝 されるためである. $\mathrm{UV} / \mathrm{O}_{3}$ 処理に適した材料は, 酸化物材 料, 酸化が許容される材料, 形成された酸化膜を後工程で除 去できる材料, 酸化膜をそのまま利用する材料, 等である. 例として $\mathrm{SiO}_{2}$ 材料を取り上げる. シリコン基板上に形成さ れた $\mathrm{SiO}_{2}$ 膜は数 $\mathrm{nm}$ の厚さでも化学的に安定であり室温下 であれば酸素䨌囲気中でも膜厚は増加しない。しかしながら $\mathrm{UV} / \mathrm{O}_{3}$ 処理は室温下でも $\mathrm{SiO}_{2}$ 膜厚を増加させる. シリコン ウエハー上の有機污染物を XPS 分析で C 元素が未検出とな る時間まで $\mathrm{UV} / \mathrm{O}_{3}$ 処理を実施した後では $\mathrm{SiO}_{2}$ 膜厚は約 0.2 $\mathrm{nm}$ 増加した ${ }^{24)}$. またFig. 5 のように $\mathrm{Si}(100)$ 基板を 2000 秒 間 $\mathrm{UV} / \mathrm{O}_{3}$ 処理（オゾン濃度 $17 \mathrm{ppm}, \mathrm{UV}$ 光波長 $254 \mathrm{~nm}$ ) したときの $\mathrm{SiO}_{2}$ 酸化膜厚の時間変化からは, 酸化の進行が 停止する傾向は見られない.このように薄膜にあっては処理

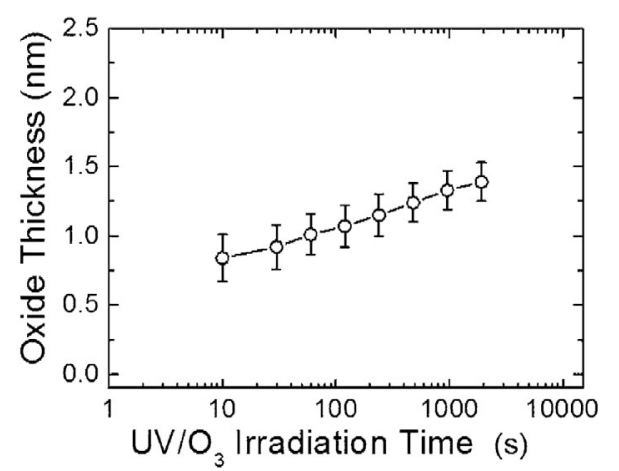

Fig. 5 Film thickness of the $\mathrm{SiO}_{2}$ film layer formed on the $\mathrm{H} /$ $\mathrm{Si}(100)$ surface treated with ozone (17 ppm)-oxygen gas mixture under UV light $(\sim 254 \mathrm{~nm})$ irradiation. The substrate temperature was maintained at $20^{\circ} \mathrm{C}$.
時間によっては無視できない膜厚の増加が引き起こされるこ とは留意しておく必要がある。

ナノ材料（縦・横・高さの少なくとも一辺の長さが 100 $\mathrm{nm}$ 以下である物質）の開発に抢いてオゾンを表面処理に使 用した例を紹介する。ナノ粒子 (NP) では, サイズのナノ メートル化により，その物性はバルクの特性よりも表面の特 性で占められるようになるため, 粒径や粒形状の把握は重要 である.ナノ粒子表面は, 保管時の粒子同土の自己融着を防 ぐため, 保護膜で覆われている. 保護膜を除去する際にプラ ズマクリーニングや加熱処理を行うとナノ粒子の形状や粒径 分布が変化するため, ナノ粒子の形状観察には表面処理方法 の選択が重要である. ポリビニルピロリドン (PVP) で覆 われた $10 \mathrm{~nm}$ 径の $\mathrm{Pt}$ ナノ粒子は, $\mathrm{UV} / \mathrm{O}_{3}$ 法で $\mathrm{PVP}$ を除去 できる。しかも粒子形状や粒径分布に影響を与えないため表 面処理法として適している ${ }^{25)} . \mathrm{UV} / \mathrm{O}_{3}$ 処理は $65 \mathrm{~nm}$ 径の $\mathrm{Pt}$ ナノ粒子の表面に作用して触媒活性を変えることもでき る26). ナノ材料である量子ドットの作製にも UV/ $/ \mathrm{O}_{3}$ が利用 されている. InAs 量子ドットをリソグラフィーで表面加工 した GaAs 基板上に核成長させるためには基板表面の高度清 浄化処理が必要である. $\mathrm{UV} / \mathrm{O}_{3}$ 法は有機溶媒（アセトン, イソプロピルアルコール, メタノール等）で取り除けなかっ た污染物を除去できる27).

$32 \mathrm{~nm}$ ハーフピッチ世代以降の次世代半導体素子製造では EUV (extreme ultraviolet) 露光が使用されるがその光学部 品の洗浄にオゾンの利用が検討されている. EUV は空気に 吸収されるため EUV 用のグレーティング28)やミラー等の光 学部品は真空装置内に設置される. ところが光学部品表面に 残留ガスが表面吸着しこれに EUV 光が照射されて反応する 々, 光学部品表面にカーボン污染層の堆積が進み光学特性が 劣化する. そこで表面清浄化をオゾンを用いたドライ洗浄で 行う. W/Mo 多層膜の EUV ミラーはオゾンガス（10 wt \% 濃度）で污染層を除去できる ${ }^{29)}$. また表面保護膜として $\mathrm{Ru}$ 層（厚さ $6 \mathrm{~nm}$ ）のある $\mathrm{Si} / \mathrm{Mo}$ 多層膜ミラーもオゾン清浄化 処理ができる30).ただ後者では吸着有機物の除去とともに $\mathrm{Ru}$ 層の酸化進行が見られ，それに伴う表面あれも確認され ている. 洗浄効果と酸化進行に伴う表面あれのバランスから は, ウエット洗浄 $\left(\mathrm{SPM}\left(\mathrm{H}_{2} \mathrm{SO}_{4}: \mathrm{H}_{2} \mathrm{O}_{2}=5: 1\right)\right.$ 洗浄や才 ゾン水）の方にメリットがあるものの, 真空装置内に設置さ れたままで部品洗浄ができる方が装置保守の点で利便性が高 $<\mathrm{UV} / \mathrm{O}_{3}$ 洗浄等によるドライ洗浄の要求も高い. そこでオ ゾン洗浄を前提にした光学部品の開発も進められており, 多

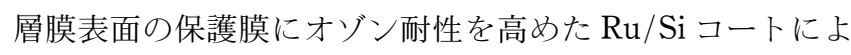

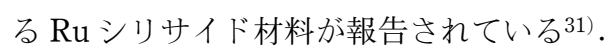

真空装置の容器内壁面の污染除去にも $\mathrm{UV} / \mathrm{O}_{3}$ 洗浄は有効 である. 走査型電子顕微鏡 $(\mathrm{SEM})$ やエネルギー分散型 $\mathrm{X}$ 線分析 (EDX) など高真空下で試料表面に電子ビーム照射 を行う分析装置の場合, 污染ガスの吸着と電子ビームによる 分解反応により試料表面にカーボン堆積が発生しやすく分析 阻害の一因となっている. 分析室内のカーボン污染源を減ら すため, 低圧水銀ランプ光（主波長 $185 \mathrm{~nm}, 254 \mathrm{~nm}$ ） と酸 素ガス導入とでオゾン（濃度 $300 \mathrm{ppm}$ ）や活性酸素を発生さ せて, 分析時のカーボン堆積速度を $90 \%$ 減らすことができ 
$ろ^{32)}$.

キログラム原器（Pt-10\% Ir 合金表面）の表面清浄処理方 法としても $\mathrm{UV} / \mathrm{O}_{3}$ 洗浄の検討が行われている33). 質量標準 は, 国際キログラム原器と各国のキログラム原器との比較の 連鎖によって維持管理されている，ところが原器質量は表面 污染により数 $\mu \mathrm{g} /$ 年増加している. 表面污染の主要物は, 水 銀·水分・炭化水素污染である ${ }^{34-36)}$. 水銀吸着によって30 $\mu \mathrm{g}$ を上限に質量が増加し，湿度による水分吸着量の変動は $10 \mu \mathrm{g}$ 程度であり, 炭化水素污染は徐々に進行する. 原器の 表面清浄には拭き取りと蒸気洗浄とを組みあわせた方法が用 いられてきたが，原器に物理的に接触せずに吸着物を除去す る $\mathrm{UV} / \mathrm{O}_{3}$ 法が検討されている. 洗浄効果をXPS 測定で調 べると, $\mathrm{PtO}, \mathrm{PtO}_{2}, \mathrm{PtOH}_{4}$ の増加を抑えつつ $\mathrm{C}=\mathrm{C}$ を持つ 炭化水素や水を減少させることができる.

$\mathrm{UV} / \mathrm{O}_{3}$ 処理方法は, イオンスパッタやラジカル照射を用 いる方法に比べて基板の結晶性を損なわないため, 薄膜堆積 前の基板に結晶性と表面清浄性の双方が必要な場合に有用で ある. $\mathrm{SrTiO}_{3}(\mathrm{STO})$ や $\mathrm{BaTiO}_{3}$ (BTO) を $\mathrm{Si}(100)$ 基板 上にエピタキシャル成長させるとき, 基板表面の清浄度がそ の薄膜構造や電子特性を大きく左右する. $\mathrm{HF}-\mathrm{NH}_{4} \mathrm{~F}$ による ウエット洗浄や $\mathrm{Ar}^{+}(1 \mathrm{keV})$ スパッタによる処理では表面 にダメージが残りその影響が無視できないが， $\mathrm{UV} / \mathrm{O}_{3}$ 法で はダメージレスで污染物が除去できる。な扰処理により表面 は酸素リッチになるもののアニール処理で回復できる程度で ある37).

シリコンウエハーの貼り合わせにも $\mathrm{UV} / \mathrm{O}_{3}$ 法は応用でき る. シリコン基板は, 表面の結晶性がよいので, 表面の付着 微粒子や污染層を除去することで, 2 枚のウエハーを貼り合 わせることができる. UV $/ \mathrm{O}_{3}$ 清浄処理を行ったガラス (PYREX, 厚さ $515 \mu \mathrm{m}$ ) 表面にシリコン基板を貼りつける こともできる ${ }^{38)}$. また SOI ウエ八をガラスに貼り合わせる こともでき，貼り合わせ後に基材をエッチング除去すれば単 結晶 $\mathrm{Si}$ 薄膜（厚さ $100 \mathrm{~nm}$ )/ガラス基板といった新規構造材 料が得られ38)，透明デバイス作製の基板材料として利用が できる.

ダイヤモンド材料は, 電子線源等への応用を目指して開発 研究が行われている39)が，レーザーアブレーションで成膜 したダイヤモンド薄膜にはダイヤモンド構造以外のカーボン が数十 $\mathrm{nm}$ 含まれておりこれを除去するために $\mathrm{UV} / \mathrm{O}_{3}$ 法が 利用されている40).

透明電極材料である ITO (indium-tin-oxide) 薄膜は UV/ $\mathrm{O}_{3}$ 処理による特性向上が図られている. ITO 薄膜の特徵 は, 透明 $(550 \mathrm{~nm}$ 可視光で $85 \%)$, 高い電気伝導率 $\left(\sim 10^{-4} \Omega \mathrm{m}\right)$ とキャリア密度，大きなバンドギャップであ り 23)，その用途は液晶ディスプレイ，タッチパネル，有機 EL な゙幅広い，有機発光素子の電極として ITO を用いる 場合 ${ }^{41,42)}$, 発光特性向上のためには表面ラフネスの低減と表 面污染の除去が必要である. UV $/ \mathrm{O}_{3}$ 表面処理は, ITO 表面 の仕事関数を向上させ，また面内の局所的な仕事関数のばら つきを, 導電 AFM で評価すると, 従来法に比べて $1 / 8$ に抑 制できる ${ }^{41)}$ ．ただし $\mathrm{UV} / \mathrm{O}_{3}$ 処理時間には最適化が必要であ り長時間行うと酸化の影響が現れ表面導電性の減少や表面あ
れの急増を招く ${ }^{41)}$. ITO 膜のバイオ応用例ではタンパク質 の電気化学評価用センサーがある. ITO 電極上のタンパク 質の酸化還元反応を調べるためには清浄な ITO 表面が必要 でありその洗浄に $\mathrm{UV} / \mathrm{O}_{3}$ は効果的である ${ }^{23)}$. ITO 代替材料 としてのアルミナドープ酸化亜鉛でも $\mathrm{UV} / \mathrm{O}_{3}$ 処理が検討さ れ, アセトン洗浄に比べて, カーボン污染量の低減と表面酸 化による組成の改善や仕事関数の改善が認められる ${ }^{43)}$.

その他多数の材料系で $\mathrm{UV} / \mathrm{O}_{3}$ 法による表面処理の有効性 が報告されている，n-InGaAsに Mo 電極を形成するとき オーミックコンタクト抵抗を低くするために清浄表面が必要 であり $\mathrm{UV}-\mathrm{O}_{3}$ 処理と $\mathrm{HCl}$ によるエッチング処理を組みあわ せた洗浄が有効である ${ }^{44)}$. トリメチルアルミニウム (TMA) よる原子層成長 (ALD) で $\mathrm{GaN}$ 表面に $\mathrm{Al}_{2} \mathrm{O}_{3}$ 薄膜を成長さ せるとき，表面をオゾン酸化した $\mathrm{GaN}$ 基板を使うと，従来 のフッ化水素酸によって清浄化した $\mathrm{GaN}$ 基板よりも反応开 イト密度が増加し $\mathrm{Al}_{2} \mathrm{O}_{3}$ 薄膜の形成時間を短縮できる ${ }^{45)}$.

$\mathrm{SiC}$ では, 表面に $\mathrm{UV} / \mathrm{O}_{3}$ 法で酸化膜（儀牲酸化膜）を形成 し，儀牲酸化膜を除去して得た表面をデバイス作製の開始表 面とすることにより，良好な電気特性のデバイスが作製でき る。これは $\mathrm{SiC} / \mathrm{SiO}_{2}$ 界面の欠陥形成の要因であったカーボ ン核を犠牲酸化膜中に取り込みそれを除去することで欠陥の 量を低減できるためである ${ }^{46)}$.

\section{5. シリコン基板の表面処理 : 酸化薄膜形成}

オゾンを用いたシリコン基板の表面処理方法として，表面 に対しオゾンを直接作用（酸化）させる方法と，基板上に薄 膜を堆積させるための前駆体としてオゾンを用いる間接利用 方法とに大別される．ここでは直接作用法として酸化膜形成 の例を述べる.

シリコン基板上に $\mathrm{SiO}_{2}$ 膜を形成する速度は使用する酸化 種で異なる.酸素雾囲気（分子状酸素）によるシリコン酸化 反応 $\left(\mathrm{Si}+\mathrm{O}_{2} \rightarrow \mathrm{SiO}_{2}\right)$ の活性化エネルギーは $0.81 \mathrm{eV}$ であり, オゾンの熱分解により生成した基底状酸素原子 O ( $\left.{ }^{3} \mathrm{P}\right)$ を 利用すると活性化エネルギーは $0.34 \mathrm{eV}$ に低下する.オゾン を用いた酸化プロセスに抢いて基板温度が $410^{\circ} \mathrm{C}$ 以下になる と，O ( $\left.{ }^{3} \mathrm{P}\right)$ の生成速度が低下するためシリコン酸化速度が 低下する.オゾンに紫外光（波長 $200 〜 300 \mathrm{~nm}$ ）を照射して 生成した励起状酸素 O ( $\left.{ }^{1} \mathrm{D}\right)$ を利用すると酸化反応の活性

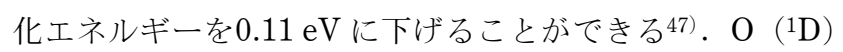
の利用により室温のシリコン基板上に数 $\mathrm{nm}$ の酸化膜を形成 できる ${ }^{48}$.

$\mathrm{UV} / \mathrm{O}_{3}$ 法では, オゾン濃度と $\mathrm{UV}$ 光強度を大きくすれば 処理効率も大きくなるが, 高出力のフラッシュUV 光を用 いて酸化膜を形成するときは基板の内部と表面との温度解離 を考慮する必要がある．この温度解離は基板をフラッシュラ ンプで瞬時加熱するときに見られ，基板の内部と表面(薄膜) とで温度差が生じる. 酸化膜は基板表面に形成されるため, 酸化膜の成長速度の制御には基板表面温度の把握が重要であ る. UV 光照射中の基板表面温度の測定は容易ではないが, $\mathrm{SiO}_{2}$ 薄膜温度を $\mathrm{SiO}_{2}$ 膜形成速度から実験的に求めた例47) て は，パワー密度 $50 \mathrm{mWcm}^{-2} \mathrm{UV}$ 光の照射により温度 $20^{\circ} \mathrm{C}$ の シリコン基板の表面温度は $300^{\circ} \mathrm{C}$ 程度に到達したと推察され 
ている.

オゾンを用いた $\mathrm{SiO}_{2}$ 形成の特徵は, 酸素ガス雾囲気下で 酸化処理を行った場合と比べて形成される $\mathrm{SiO}_{2}$ 膜の膜質が 向上する点にある ${ }^{49)}$. 希フッ化水素酸による $\mathrm{SiO}_{2}$ 膜のエッ チング速度は, $\mathrm{SiO}_{2}$ 膜の深さ方向について密度 · 応力 ·化 学結合状態等の変化を総合的に示すとされる.オゾン形成酸 化膜と熱酸化膜のエッチング特性の比較より, 熱酸化膜では エッチング速度の変化する変質層（構造遷移層）が界面付近 にあり，一方オゾン形成酸化膜は界面まで均質である。すな わち界面付近では酸化膜の構造が両者で異なることが示唆さ れる50). 中エネルギーイオン散乱分光法 (MEIS) の結果も 構造の違いを示唆しており, 熱酸化膜には構造遷移層中での 局所結晶構造の存在が示唆されるが，オゾン形成酸化膜には 局所結晶構造をとる層がみられず $\mathrm{Si}$ 原子変位方向のランダ ムなアモルファス構造となっている51). $\mathrm{SiO}_{2}$ 膜を界面付近 の遷移層の有無で模式的に現すと, $\mathrm{SiO}_{2}$ 層が均一な密度の モデル (Fig. 6(a)） と, $\mathrm{SiO}_{2}$ 層が界面付近の遷移層とその 上のバルク層で構成され互いに密度が異なるモデル（Fig. 6 （b)）とである.オゾンで形成した酸化膜は (a)に近く, 酸 素で形成した熱酸化膜は(b)に近い。このように, 表面処理 (酸化処理) で形成された薄膜で, 化学量論構造は同じであ るが，密度構造が異なる場合が存在する. Fig. 6(a) (b)のよ うな薄膜を識別するためには薄膜中の密度構造を解析できる 手法が必要である。

薄膜の厚さや密度を計測する方法としてX線反射率 (XRR) 法を取り上げる. 一般に薄膜の厚さを測る各種表面 分析法では定量分析のために仮定の設定が必要である.たと えばXPS では単位体積あたりの元素の個数の情報を得る計 測法であるので, 膜厚に換算するには密度に関する情報を与 える必要がある，それに比べて XRR 法は膜厚を直接測定で きる方法である. XRR 測定法は, X 線を薄膜試料表面に斜 めに入射してその反射 $\mathrm{X}$ 線強度を測定し入射角度を走査し て反射率プロファイルを得る方法である. 反射率プロファイ ルには振動パターンが現れ（Fig. 7) その振動周期は薄膜の 膜厚の情報を持ち, また薄膜の密度 ・ ラフネスの情報も得ら れる. XRR 法は単層膜だけでなく多層膜の解析も行うこと ができるため, 多層となっているナノ構造材料について埋も れた界面や各層厚さ・密度の構造変化などを明らかにするの に適しており, また表面処理による改質効果を厚さ方向に高 分解能で解析できるツールである.

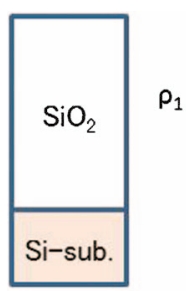

(a)

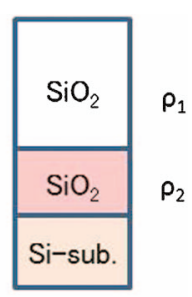

(b)
Fig. 6 (a) $\mathrm{SiO}_{2}$ single-layer model with a density of $\rho 1$, and (b) $\mathrm{SiO}_{2}$ double-layer model with densities of $\rho 1$ and $\rho 2$. The intermediate $\mathrm{SiO}_{2}$ layer is thought to be a transition layer with a density of $\rho 2$, different from the bulk density of $\rho 1$.
Fig. 8 の装置のゴニオメータは, 角度の特定標準器と同 様のしくみを持つ角度自己較正機能 52 を備えている. 膜厚 測定は $\mathrm{X}$ 線の波長と $\mathrm{X}$ 線入射角度で決定されるので両者が

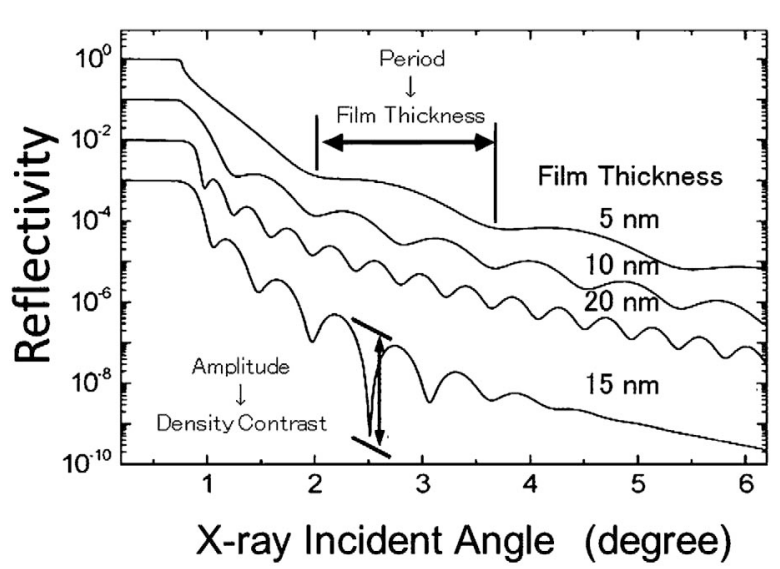

Fig. 7 The simulated $X$-ray reflectivity of thin films formed on the substrate as a function of the $\mathrm{X}$-ray incident angle. The film thicknesses from top to bottom were set to be 5,10 , 20 , and $15 \mathrm{~nm}$. The larger roughness of the interface was given for the thin film with the thickness of $15 \mathrm{~nm}$.

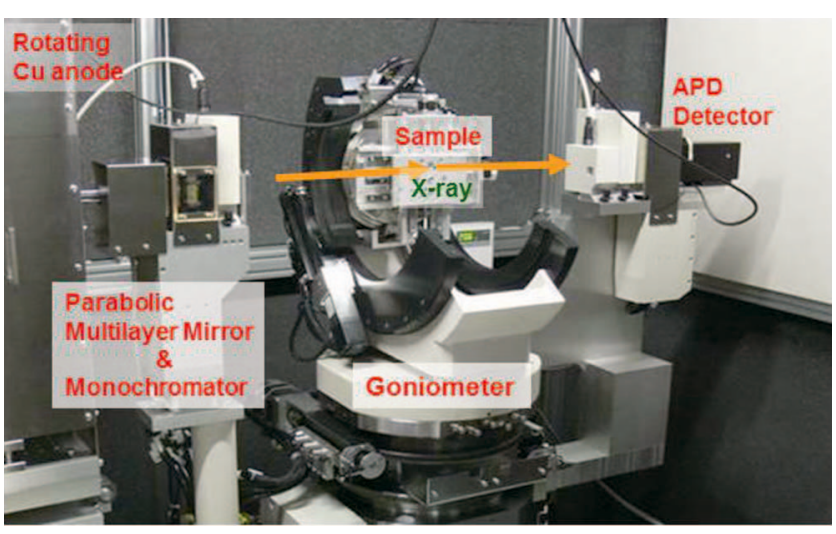

Fig. 8 Apparatus of the traceable XRR system. The goniometer has an angle self-calibration system. The sample is rotated at an angle of $\theta$, while the $\mathrm{X}$-ray detector is rotated at an angle of $2 \theta$. The $\mathrm{X}$-ray beam was focused and aligned with a parabolic multilayer mirror and apertures.

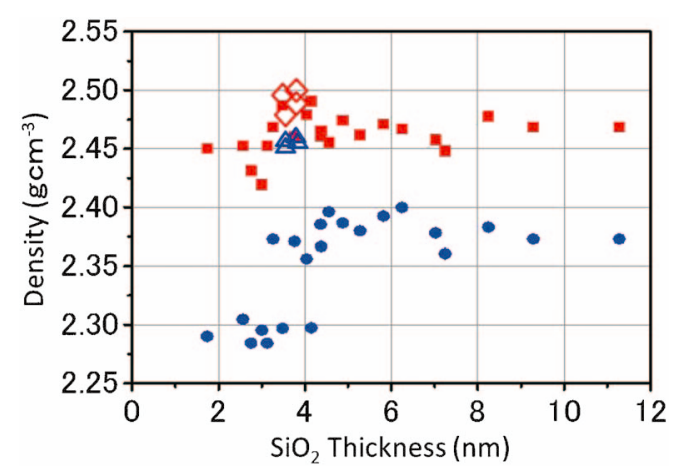

Fig. 9 The $\mathrm{SiO}_{2}$ film density of the bulk layer $(\square)$ and transition layer $\left(-\right.$ for a thermally grown $\mathrm{SiO}_{2}$ film at a substrate temperature of $750^{\circ} \mathrm{C}$. The horizontal axis shows the total film thickness of $\mathrm{SiO}_{2}$ layer. The bulk-layer density $(\diamond)$ and the transition-layer density $(\triangle)$ of the ozone-formed $\mathrm{SiO}_{2}$ film are also plotted. 
校正されれば正確な厚さ測定が可能である．本装置での膜厚 測定に抢ける不確かさは $10^{-3} \mathrm{~nm}$ である。な打入射 $\mathrm{X}$ 線は $\mathrm{CuK}_{\alpha 1}$ 線 $\left(\mathrm{xu}\left(\mathrm{CuK}_{\alpha 1}\right) ; 1.00209952(53) \times 10^{-13} \mathrm{~m}\right)^{53)}$ であ り解析時には $\mathrm{CuK}_{\alpha 1}=0.15406 \mathrm{~nm}$ を用いている.

酸化膜の密度構造について, 酸素により形成した酸化膜 (熱酸化膜) をXRR 法で解析した結果を Fig. 9 に示す54). 熱酸化膜は, 界面付近に存在する遷移層の密度がバルク層に 比べて数\%高い。このときの遷移層の厚さは約 $1 \mathrm{~nm}$ であ る. またバルク層の密度は, $\mathrm{SiO}_{2}$ 膜が成長して $4 \mathrm{~nm}$ 付近に なると密度が急に大きくなる，バルク層や界面層のいずれの 密度も, 酸化膜形成時の基板の温度に依存して変化する. Fig. 9 には，オゾンガスで形成した酸化膜の遷移層の密度と バルク層の密度を併せて示す。オゾン形成酸化膜ではバルク 層と界面層の密度の差が熱酸化膜に比べると小さい。すなわ ち Fig. 6 (a)で示すような密度が全体が均一な密度の $\mathrm{SiO}_{2}$ 層 であるモデルに近い．XRR 法は輝度の高い放射光 X 線を用 いることでより詳細な解析ができる. CVD で形成した $\mathrm{SiO}_{2}$ 薄膜をオゾンガスで表面処理したときの $\mathrm{SiO}_{2}$ 薄膜の密度構 造変化を捉えることができる55). 薄膜情報をナノレベルの 精度で得ることができるXRR 法はその利用の広がりが期待 される。

\section{6. その他のオゾン利用技術}

オゾン分子とオゾンを分解して得られる酸素の活性種 $\mathrm{O}\left({ }^{3} \mathrm{P}\right)$ や $\mathrm{O}\left({ }^{1} \mathrm{D}\right)$ は反応性が大きく異なり，それらが反応す る化学結合が異なるため, 用途に応じて使い分けることがで きる.

カーボンナノチューブ（CNT）は炭素による六員環ネッ トワークを持ちオゾンの直接反応が可能であり, CNT 特性 の制御にオゾン処理法が試みられている. CNT は先端の小 さな曲率半径を生かして電子線源への応用が図られており, CVDを用いたアレイ状電子線源等の用途が期待されてい る.オゾンは，CNTの直径が小さいものと反応しやすい性 質を持ち ${ }^{56)}$ ， また曲率の小さい CNT 先端部と積極的に反応 して開裂させる性質を持つ ${ }^{57)}$. これを利用して CNT 先端を 開裂し先端部をさらに鋭利にすると, 電界放出電流が 8 倍 に向上する ${ }^{57)}$ ．また CNT は高い電気伝導性をもつナノワィ ヤーとして次世代電子デバイスへの応用が図られている。 マ ルチウォール CNT をオゾン処理すると, 最外殼の一部が反 応して欠陥が導入され内側殼と接合する箇所が現れる。これ により CNTの電気伝導度の向上が可能である ${ }^{56)}$.

1,1,1,3,3,3-ヘキサメチルジシラザン（HMDS）は，オゾ ンと UV 光照射との併用によって基板上に $\mathrm{SiO}_{2}$ 膜を堆積す るための CVD 用ガスとして検討されている58). HMDSの 特徵はオゾンと混合しても容易に反応しないこと, UV 光 （２48 nm） 照射を併用すると分解反応が始まること ${ }^{59,60)} に$ ある. UV 光下の HMDS とオゾンの気相中での反応 ${ }^{60)}$ は, オゾンの解離による活性種の生成, HMDSの Si-NH-Si 結 合の切断とそれによる $\left(\mathrm{CH}_{3}\right)_{3}-\mathrm{Si}$ や $\mathrm{HN}-\mathrm{Si}-\left(\mathrm{CH}_{3}\right)_{3}$ の生 成，それらの $\mathrm{CH}_{3}$ 基と活性種との反応による $\mathrm{C}=\mathrm{O}$ 結合や $\mathrm{C}-\mathrm{O}$ 結合の生成, により進行する. $\mathrm{SiO}_{2}$ 生成反応は気相中 ではわずかであるが，基板上での $\mathrm{SiO}_{2}$ 膜の堆積速度は大き
く $30 \mathrm{~nm} /$ 分に達する。なお $\mathrm{HMDS}$ で形成された $\mathrm{SiO}_{2}$ 膜は 電気的絶縁特性にも優れている61).

\section{7. まと め}

オゾンによる表面処理の効果はオゾンが持つ高い酸化反応 性に基づいている. その反応機構はオゾンやオゾン分解反応 により生成されるラジカルと対象物との反応が導いた結果で ある.オゾン処理により, 従来の薬液や有機溶媒による処理 に替えることが可能である. ドライ洗浄法としてもウエット 洗浄法としても使えるオゾンの利用技術の裙野は広く，また 薄膜形成やナノ材料を利用した新材料開発にも利用が広がっ ている. 分解すれば無害の酸素となる環境適合性を持つオゾ ンはさらに応用分野が広がることが期待される.

\section{[文献〕}

1) R. E. Buhler, J. Staehelin and J. Hoigne: J. Phys. Chem., 88 (1984) 2560.

2) J. Staehelin, R. E. Buhler and J. Hoigne: J. Phys. Chem., 88 (1984) 5999.

3) I. Somiya: Ozone Hand Book (Sanyu Syobo, Yokohama, 2004), p. 97 [in Japanese].

4) J. Lee, K. Park and S. Lim: J. Electrochem. Soc., 155 (2008) D547.

5) M. Takahashi, H. Ishikawa, T. Asano and H. Horibe: J. Phys. Chem. C, 116 (2012) 12578.

6) H. Y. Lee, H. S. Uhm, Y. F. Hong and Y. H. Park: Appl. Phys. Lett., 92 (2008) 174102.

7) D. H. Eom, G. B. Lim, J. G. Park and A. A. Busnaina: Jpn. J. Appl. Phys., 43 (2004) 3335.

8) A. Abbadie, J. M. Hartmann, P. Besson, D. Rouchon, E. Martinez, P. Holliger, C. Di Nardo, Y. Campidelli and T. Billon: Appl. Surf. Sci., 254 (2008) 6793.

9) S. Noda, K. Kawase, H. Horibe, M. Kuzumoto and T. Kataoka: J. Electrochem. Soc., 152 (2005) G73.

10) Y. Lee, J. Y. Lee, K. T. Im and S. Lim: Jpn. J. Appl. Phys., 48 (2009) 056511.

11) K. Uemura, T. Haibara and T. Adachi: Electrochim. Acta, 53 (2007) 16

12) C. K. Chan, G. Y. Hsiung, C. C. Chang, R. Chen, C. Y. Yang, C. L. Chen, H. P. Hsueh, S. N. Hsu, I. Liu and J. R. Chen: J. Phys., Conf. Ser., 100 (2008) 092025

13) K. Koike, H. Kuriyama, G. Inoue, T. Yamamoto and S. Fukuzaki: Kagaku Kogaku Ronbun, 28 (2002) 73.

14) K. Koike, G. Inoue, M. Suzuki, J. Saida and I. Komatsu: J. Chem. Eng. Jpn., 31 (1998) 195.

15) S. Fukuzaki, K. Koike, K. Takahashi and S. Yamada: J. Surf. Finish. Soc. Jpn., 57 (2006) 440.

16) T. Ohmi, A. Ohki, M. Nakamura, K. Kawada, T. Watanabe, Y. Nakagawa, S. Miyoshi, S. Takahashi and M. S. K. Chen: J. Electrochem. Soc., 140 (1993) 1691.

17) R. O. Suzuki, T. Ogawa and R. Kondo: J. Am. Ceram. Soc., 91 (2008) 1148.

18) R. O. Suzuki and K. Ohta: Oxid. Met., 65 (2006) 39.

19) M. Yoshida, A. Seki, Y. Shirai and T. Ohmi: J. Vac. Sci. Technol. A, 17 (1999) 1059

20) Y. Matsuda, K. Takeda and S. Azuma: Mater. High Temp., 17 (2000) 299.

21) A. Kurokawa, S. Ichimura and K. Odaka: Japanese Patent No. 2004-131779 (2004/04/30).

22) T. Momose, Y. Maeda, K. Asano and H. Ishimaru: J. Vac. Sci. Technol. A, 13 (1995) 515.

23) M. Tominaga, N. Hirata and I. Taniguchi: Electrochem. Commun., 7 (2005) 1423.

24) M. P. Seah and S. J. Spencer: J. Vac. Sci. Technol. A, 21 
(2003) 345.

25) C. Aliaga, J. Y. Park, Y. Yamada, H. S. Lee, C. K. Tsung, P. Yang and G. A. Somorjai: J. Phys. Chem. C, 113 (2009) 6150.

26) F. J. Vidal-Iglesias, J. Solla-Gulloacuten, E. Herrero, V. Montiel, A. Aldaz and J. M. Feliu: Electrochem. Commun., 13 (2011) 502.

27) M. Helfrich, D. Z. Hu, J. Hendrickson, M. Gehl, D. Ruumllke, R. Groumlger, D. Litvinov, S. Linden, M. Wegener, D. Gerthsen, T. Schimmel, M. Hetterich, H. Kalt, G. Khitrova, H. M. Gibbs and D. M. Schaadt: J. Cryst. Growth, 323 (2011) 187.

28) T. Harada, S. Yamaguchi, M. Itou, S. Mitani, H. Maezawa, A. Mikuni, W. Okamoto and H. Yamaoka: Appl. Opt., 30 (1991) 1165.

29) M. Niibe, K. Koida and Y. Kakutani: J. Vac. Sci. Technol. B, 29 (2011) 011030.

30) L. Belau, J. Y. Park, T. Liang, H. Seo and G. A. Somorjai: J. Vac. Sci. Technol. B, 27 (2009) 1919.

31) J. Y. Park, L. Belau, H. Seo and G. A. Somorjai: J. Vac. Sci. Technol. B, 29 (2011) 041602.

32) H. D. Wanzenboeck, P. Roediger, G. Hochleitner, E. Bertagnolli and W. Buehler: J. Vac. Sci. Technol. A, 28 (2010) 1413.

33) J. Berry, S. Davidson, P. Barat and R. Davis: Metrologia, 48 (2011) 181.

34) P. J. Cumpson and M. P. Seah: Metrologia, 33 (1996) 507.

35) J. Berry, S. Downes and S. Davidson: Metrologia, 47 (2010) 410.

36) P. J. Cumpson and M. P. Seah: Metrologia, 31 (1994) 21.

37) F. Amy, A. Wan, A. Kahn, F. J. Walker and R. A. McKee: J. Appl. Phys., 96 (2004) 1601.

38) H. S. Kim, R. H. Blick, D. M. Kim and C. B. Eom: Appl. Phys. Lett., 85 (2004) 2370.

39) S. Y. Mun, K. C. Shin, W. I. Choi, J. Y. Kim, D. B. Kim, S. J. Kang and Y. H. Jeong: J. Electrochem. Soc., 153 (2006) D213.

40) J. Smedley, C. Jaye, J. Bohon, T. Rao and D. A. Fischer: J. Appl. Phys., 105 (2009) 123108 (5 pp.).

41) S. H. Chen: J. Appl. Phys., 97 (2005) 73713.

$42)$ S. K. So, W. K. Choi, C. H. Cheng, L. M. Leung and C. F. Kwong: Appl. Phys. A, 68 (1999) 447.

43) W. Wang, Q. Feng, K. Jiang, J. Huang, X. Zhang, W. Song and R. Tan: Appl. Surf. Sci., 257 (2011) 3884.

44) A. Baraskar, M. A. Wistey, V. Jain, E. Lobisser, U. Singisetti,
G. Burek, Y. J. Lee, B. Thibeault, A. Gossard and M. Rodwell: J. Vac. Sci. Technol. B, Microelectron. Nanometer Struct., 28 (2010) C5I7.

45) P. Sivasubramani, T. J. Park, B. E. Coss, A. Lucero, J. Huang, B. Brennan, Y. Cao, D. Jena, H. Xing, R. M. Wallace and J. Kim: Phys. Status Solidi, 6 (2012) 22.

46) V. V. Afanas'ev, A. Stesmans, M. Bassler, G. Pensl, M. J. Schulz and C. I. Harris: Appl. Phys. Lett., 68 (1996) 2141.

47) N. Kameda, T. Nishiguchi, Y. Morikawa, M. Kekura, K. Nakamura, T. Ushiyama, H. Nonaka and S. Ichimura: Anal. Sci., 26 (2010) 273.

48) A. Tosaka, H. Nonaka, S. Ichimura and T. Nishiguchi: J. Appl. Phys., 101 (2007) 034909.

49) A. Kurokawa: Shinku, 44 (2001) 707.

50) K. Nakamura, A. Kurokawa and S. Ichimura: Thin Solid Films, 343 (1999) 361

51) A. Kurokawa, K. Nakamura, S. Ichimura and D. W. Moon: Appl. Phys. Lett., 76 (2000) 493.

52) T. Watanabe, H. Fujimoto and T. Masuda: J. Phys., Conf. Ser. 13 (2005) 240.

53) $\mathrm{Cu} \mathrm{x}$ unit in NIST Reference on Fundamenta Physical Constants, NIST, 2013, http://physics.nist.gov/cgi-bin/cuu/Value?xucukalph1

54) K. Odaka, A. Kurokawa, Y. Azuma, L. L. Zhang and T. Fujimoto: Jpn. J. Appl. Phys., 51 (2012) 091301.

55) K. Kawase, S. Noda, T. Nakai and Y. Uehara: Jpn. J. Appl. Phys., 48 (2009) 101401.

56) S. Agrawal, M. S. Raghuveer, H. Li and G. Ramanath: Appl. Phys. Lett., 90 (2007) 193104

57) S. C. Kung, K. C. Hwang and I. N. Lin: Appl. Phys. Lett., 80 (2002) 4819.

58) T. Nishiguchi, T. Noyori, Y. Morikawa, M. Kekura, H. Nonaka and S. Ichimura: Shinku, 48 (2005) 313.

59) K. Nakamura, H. Nonaka, N. Kameda, T. Nishiguchi and S. Ichimura: J. Vac. Soc. Jpn., 51 (2008) 224.

60) K. Nakamura, H. Nonaka, N. Kameda, T. Nishiguchi and S. Ichimura: Jpn. J. Appl. Phys., 47 (2008) 7349.

61) N. Kameda, T. Nishiguchi, Y. Morikawa, M. Kekura, H. Nonaka and S. Ichimura: Jpn. J. Appl. Phys., 48 (2009) 05DB01. 